\title{
Antibiogram and Plasmid Profile of Escherichia Coli Isolates in Well Water In Akure, South Western Nigeria
}

\author{
Bello* $^{*}$ B.K ${ }^{1}$, Adebolu, T.T ${ }^{2}$ and Oyetayo, V.O ${ }^{2}$ \\ Department of Microbiology, Federal University of Technology, Akure, Ondo State, Nigeria.
}

\begin{abstract}
Well water samples sourced from Akure, Ondo State, Nigeria were analyzed using standard and analytical methods to determine the level of divergence of Escherichia coli, in the well water, its antibiogram and the plasmid profile. A total of 400 well water samples were analyzed during the raining and dry season. The mean value of $E$.coli count obtained ranged from $1.0 \times 10^{3} \mathrm{cfu} / \mathrm{ml}$ to $3.2 \times 10^{3} \mathrm{cfu} / \mathrm{ml}$. Highest E. coli count was obtained from the sample sourced from Isolo while lowest from FUTA environment. In all, E. coli were isolated from (76) well water sample representing 19\% of the 400 sample sourced during the dry season and 108 representing 27\% 400 well water sample collected during the raining season. Overall, of 184 E. coli isolates from different well water sourced from different location in Akure were tested against the selected antimicrobial agent. Fifty (50) representing $27.17 \%$ of the 184 E. coli isolates showed multiple resistances to (10) antimicrobial agents tested. However, of the ten antimicrobial agents tested, resistance was highest to AM (37) $20.1 \%$ follow by SXT (32) $17.4 \%$ and $\mathrm{CH}(31) 16.85 \%$. E. coli isolates obtained from Isolo community revealed the highest prevalence of resistance to antimicrobial agent (SXT, CH, S, SP, CPS, AM, AU, and CN). The

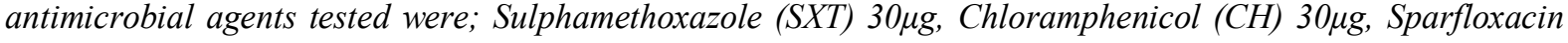

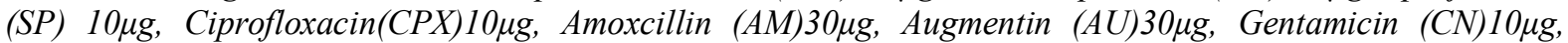

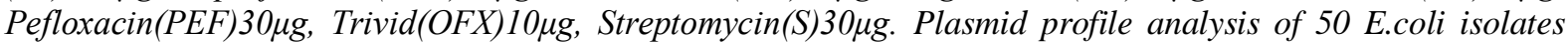
that showed multiple resistances by agarose gel electrophoresis showed a total of 48 different plasmid bands occurring in various combinations. The microbiological analysis of the well water sample used in this research did not meet the recommended limits and could pose a serious health risk to consumers.
\end{abstract}

KEY WORDS: Antibiogram, Antibiotic, E. coli, Plasmid, Well water,

\section{INTRODUCTION}

About $70 \%$ of earth is made up of water. In spite of this, good quality water for human usage is still inadequate. About 1.2 billion people worldwide according to [1] lack access to safe drinking water. Almost 30\% of population of people in developing country do not have access to good quality water. Dwindling municipal water supply leads to water and sanitation crisis. For their domestic needs, people fall back on dubious water sources, many of which contain dangerous contaminants [2]. Water for their daily needs are majorly sourced from river, stream, well and pond [3]. However, in most towns in south western Nigeria, people depend on well water for all domestic activities. These water sources are frequently exposed to microbial contamination from humans, animals and the environment [4,5]. Potential sources of these pathogens in water include wastewater effluents, combined sewer overflows, runoff from urban land, animal wastes, and municipal waste sludges disposed off on land or in water [6,7]A significant proportion of inhabitants of these communities are therefore exposed to water-borne diseases $[8,9]$ which continues to grow with the increasing demands for potable water [10]. Inadequate supply of water free from pathogenic microorganisms has a significant and devastating impact on public health. Water intended for human consumption must therefore be free from microorganisms and chemical substances that constitute health hazards. The microorganisms most commonly used as indicator of microbial pollution, are Escherichia coli and the coliform group as a whole [11]. A well water is an excavation or structure created in the ground by digging, driving, boring or drilling to access water in underground aquifers. The well water is drawn by an electric submersible pump or a mechanical pump (eg from a water-pumping windmill. It can also be drawn up manually using containers, such as buckets, that are raised by hand. Although not essential, a storage tank with a pressure of 40-60 psi is usually added to the system (after the pump), so the pump does not need to operate constantly.

To reduce the electricity required to pump up the water, often, a cistern is also added along with a small second pump [12]. Wells can vary greatly in depth, water volume and water quality. Well water typically contains more minerals in solution than surface water and may require treatment to soften the water by removing minerals such as arsenic, iron and manganese contents. 
A well is made by reaching groundwater in the water table. Groundwater is stored naturally below the Earth's surface. Most groundwater originates as rain or snow that seeps into the ground and collects. [13]

Escherichia coli are found as normal flora in the human intestine. E. coli and related bacteria constitute about $0.1 \%$ of gut flora, and fecal-oral transmission is the major route through which pathogenic strains of the bacterium cause disease [14]. The organism is usually harmless in the intestinal lumen. Moreover, even the most robust members of our species may be susceptible to infection by one of several highly adapted E. coli clones which together have evolved the ability to cause a broad spectrum of human diseases. Infections due to pathogenic E. coli may be limited to the mucosal surfaces or can disseminate throughout the body.

Water supply in Akure metropolis is mainly from wells. The water from the well is often contaminated by surface or runoff waters especially during rainy season and indiscriminate dumping of refuse around the wells. In view of this, this research is focusing on the Antibiogram and Plasmid Profile of Escherichia Coli which is the organism that is used as indicator of faecal pollution

\section{MATERIALS AND METHODS}

The water samples used in this research were sourced from four hundred (400) selected wells in Akure, southwestern Nigeria.

\subsection{Sample collection}

A total of four hundred well were sampled. Water was collected from the well using sterile bottle with tight covered. The water was collected by holding the bottle at the bottom while plunging the mouth into the water and covered immediately after collecting the water sample. The bottle was filled leaving about $30 \mathrm{~mm}$ of empty space to allow mixing during laboratory analysis. Water samples were immediately transported to the laboratory and store at $4^{0} \mathrm{C}$ prior analysis.

\subsection{Isolation and identification of Escherichia coli}

Isolation and identification of Escherichia coli were done using Eosine methylene blue agar (EMB). Individual colonies showing a green metallic sheen on EMB agar were further confirmed using biochemical tests $[15,16]$. The biochemical tests used to further differentiate $E$. coli from other feacal coliform bacteria were indole, methyl-red, voges-proskaher and citrate test [17].

\subsection{Antibiotic sensitivity tests}

The antibiotic sensitivity test of the E. coli isolates was determined using the disc diffusion method [18].

\subsection{Plasmid Analysis}

Plasmid profile of $E$. coli isolates were analysed by $0.8 \%$ agarose gel electrophoresis after staining with ethidium bromide and the DNA bands were visualised by UV-transilluminator.

\section{RESULTS}

The mean value of $E$.coli count obtained during the dry season ranged from $1.0 \mathrm{x} 10^{3} \mathrm{cfu} / \mathrm{ml}$ to $2.5 \times 10^{3} \mathrm{cfu} / \mathrm{ml}$. Highest $E$. coli count was obtained from the sample sourced from Isolo $2.5 \times 10^{3} \mathrm{cfu} / \mathrm{ml}$. While lowest was obtained from sample sourced from Ijoka. During the raining season, an increase was however noted on the E. coli count indicating that the water has been heavily polluted with faecal contamination, the values ranged from $3.0 \times 10^{3} \mathrm{cfu} / \mathrm{ml}$ to $3.2 \times 10^{3} \mathrm{cfu} / \mathrm{ml}$. Highest E.coli count was obtained from Isolo $\left(3.2 \times 10^{3} \mathrm{cfu} / \mathrm{ml}\right)$ while lowest from FUTA metropolis. In all, E. coli were isolated from (76) well water sample representing $19 \%$ of the 400 sample sourced during the dry season and 108 representing $27 \% 400$ well water sample collected during the raining season. Fig 1 . This result is contrary to WHO recommendation of zero $E$. coli in $100 \mathrm{ml}$ water sample. 


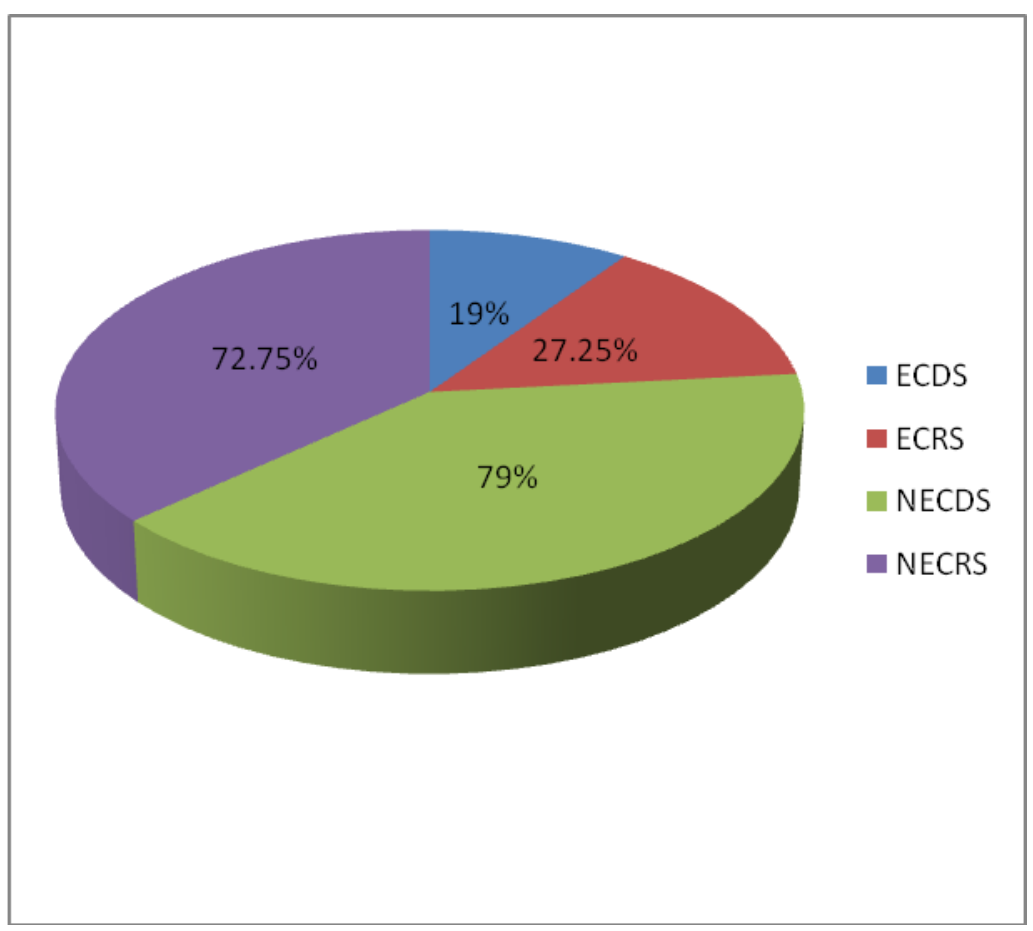

Fig1: E. coli count of well water samples collected in Akure metropolis at two different seasons of the year

$\mathrm{ECDS}=$ E. coli dry season

$\mathrm{ECRS}=E$. coli raining season

NECDS $=$ No $E$. coli Dry season

NECRS $=$ No E. coli $\mathrm{WHO}$ raining season

Overall, of 184 E. coli isolates from different well water sourced from different location in Akure were tested against the selected antimicrobial agent. Fifty (50) representing $27.17 \%$ of the $184 \mathrm{E}$. coli isolates showed multiple resistant to (10) antimicrobial agents tested. During the dry season 17 representing $22.37 \%$ of the 76 isolate tested showed multiple resistant while $33 \mathrm{E}$. coli isolates representing $30.56 \%$ of the 108 isolate tested were resistance to many antibiotics during the raining season. However, 59 isolates representing $77.63 \%$ of the 76 isolates tested were sensitive during the dry season while 75 representing $63.4 \%$ of the 108 isolates tested were sensitive to one or more antibiotic agents tested during the raining season. Fig 2 . The prevalence of resistance of the E. coli isolates to each antimicrobial agent tested during the dry season were; SXT (17) $9.2 \%$; CH (13)7.06\%; SP (9)4.89\%; CPX (14)7.60\%; AM (21) $11.4 \%$; AU (8) 4.3\%; PEF (5) $2.72 \%$;CN (8) $4.3 \%$ OFX (4) $2.17 \%$; S (18) 9.78\%. During the raining season the prevalence were; SXT (32) $17.4 \%$; CH (31)16.85\%; SP (27)14.68\%; CPX (23)12.5\%; AM (37) 20.1\%; CN 10.87\%; AU (17) 9.2\%; PEF (15) 8.15\%; OFX (18) $9.78 \%$; S (29) 15.76\%. Fig 2.

However, of the ten antimicrobial agents tested, resistance was highest to AM (37) 20.1\% follow by SXT (32) $17.4 \%$ and $\mathrm{CH}(31) 16.85 \%$. E.coli isolates obtained from Isolo community revealed the highest prevalence of resistance to antimicrobial agent (SXT, CH, S, SP, CPS, AM, AU, and CN). Isolates from Isolo metropolis showed the highest resistance pattern indicating the well water from this area were of poor microbiological

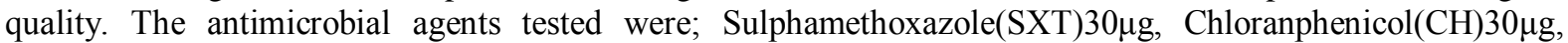

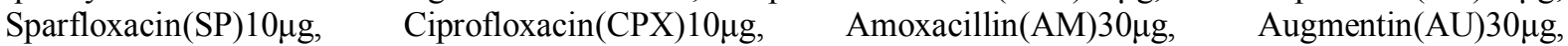

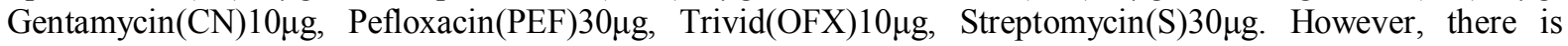
variation in the prevalence of the resistance of the $E$. coli isolates to the antimicrobial agent tested. 


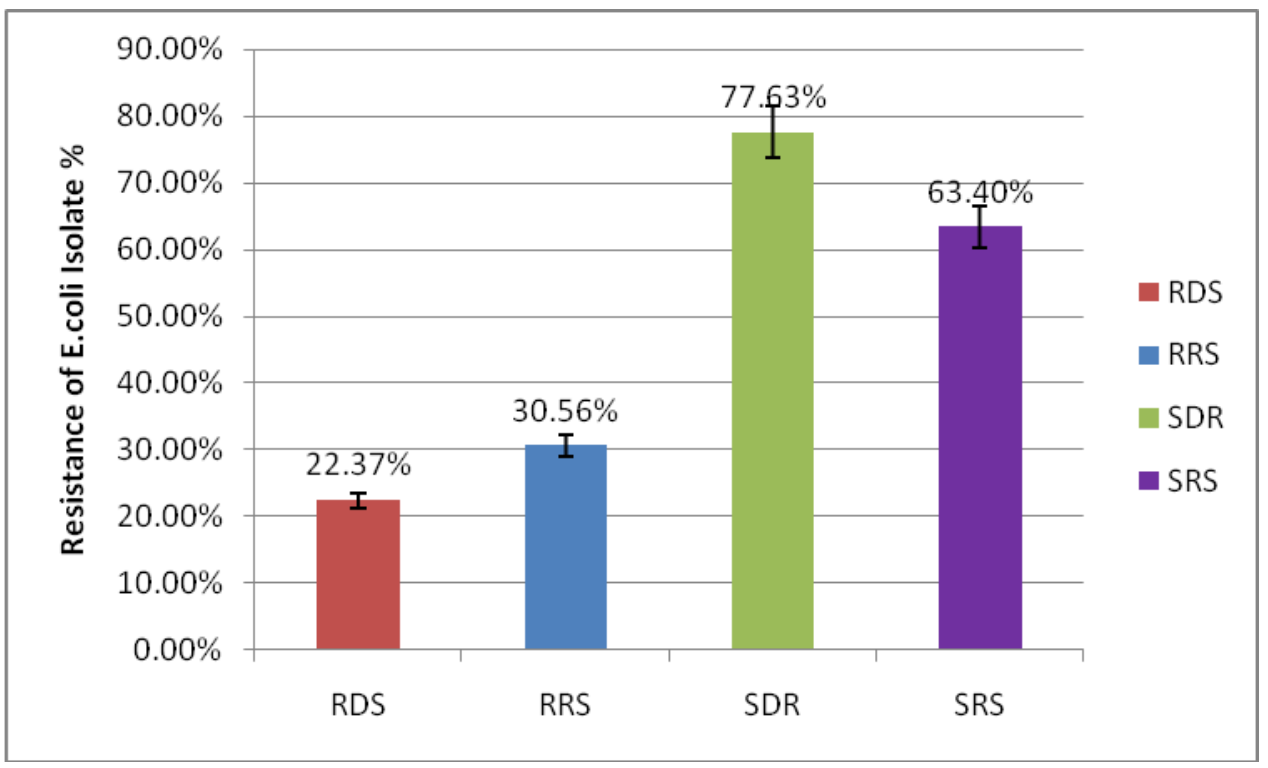

Fig 2: Resistance pattern of $E$. coli isolates of well samples collected in Akure metropolis at two different season of the year

RDS Resistant dry season

RRS Resistance raining season

SDS Sensitive dry season

SRS Sensitive raining season

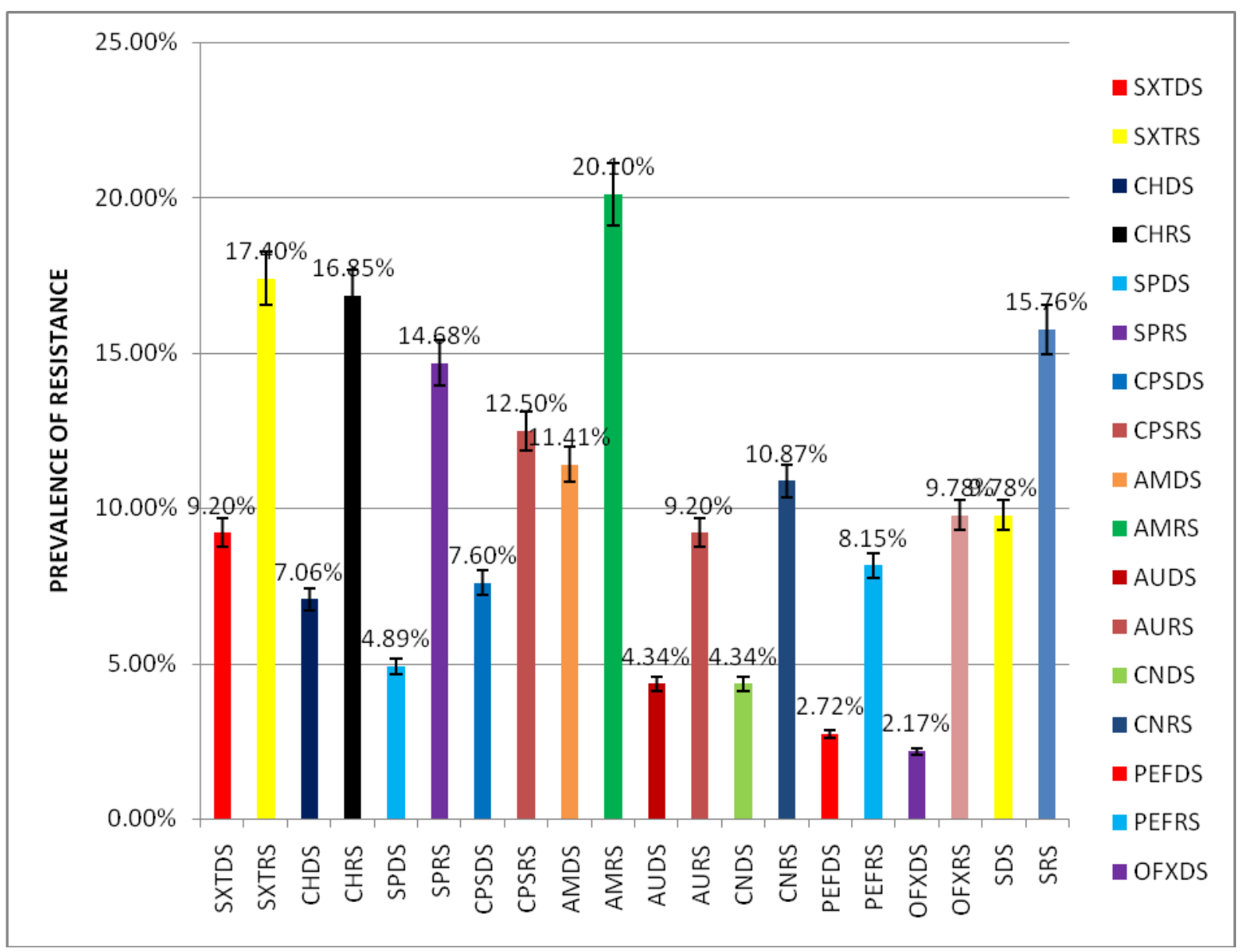

Fig 3: Prevalence of resistance of E. coli isolates from well water in Akure metropolis SXTDS = Resistance to Sulphamethoxazole (SXT) dry season 
SXTDS = Resistance to Sulphamethoxazole (SXT) raining season

CHDS $=$ Resistance to Chloranphenicol $(\mathrm{CH})$ dry season

CHDS $=$ Resistance to Chloranphenicol $(\mathrm{CH})$ raining season

SPDS = Resistance to Sparfloxacin (SP) dry season

SPRS $=$ Resistance to Sparfloxacin raining season

CPSDS = Resistance to Ciprofloxacin(CPX) dry season

CPSRS=Resistance to Ciprofloxacin(CPX) raining season

AMDS $=$ Resistance to Amoxacillin (AM) dry season

AMRS $=$ Resistance to Amoxacilli(AM) raining season

OFXDS $=$ Resistance to Trivid(OFX) dry season

OFXDS $=$ Resistance to Trivid(OFX) raining season

$\mathrm{SDS}=$ Resistance to Streptomycin $(\mathrm{S})$ dry season

$\mathrm{SRS}=$ Resistance to Streptomycin $(\mathrm{S})$ dry season

AUDS $=$ Resistance to Augmentin(AU) dry season

AURS $=$ Resistance to Augmentin (AU) rain season

CNDS $=$ Resistance to Gentamycin $(\mathrm{CN})$ dry season

$\mathrm{CNRS}=$ Resistance to Gentamycin $(\mathrm{CN}) \mathrm{R} \mathrm{S}$

PEFDS $=$ Resistance to Pefloxacin(PEF) dry season

PEFRS $=$ Resistance to Pefloxacin $(\mathrm{PEF}) \mathrm{R}$. season

Fig. $4 \& 5$ shows the plasmid profile of the $E$. coli isolates that shows multiple resistances to one or more antibiotics. Plasmid profile analysis of 50 E.coli isolates by agarose gel electrophoresis showed a total of 48 different plasmid bands occuring in various combinations.

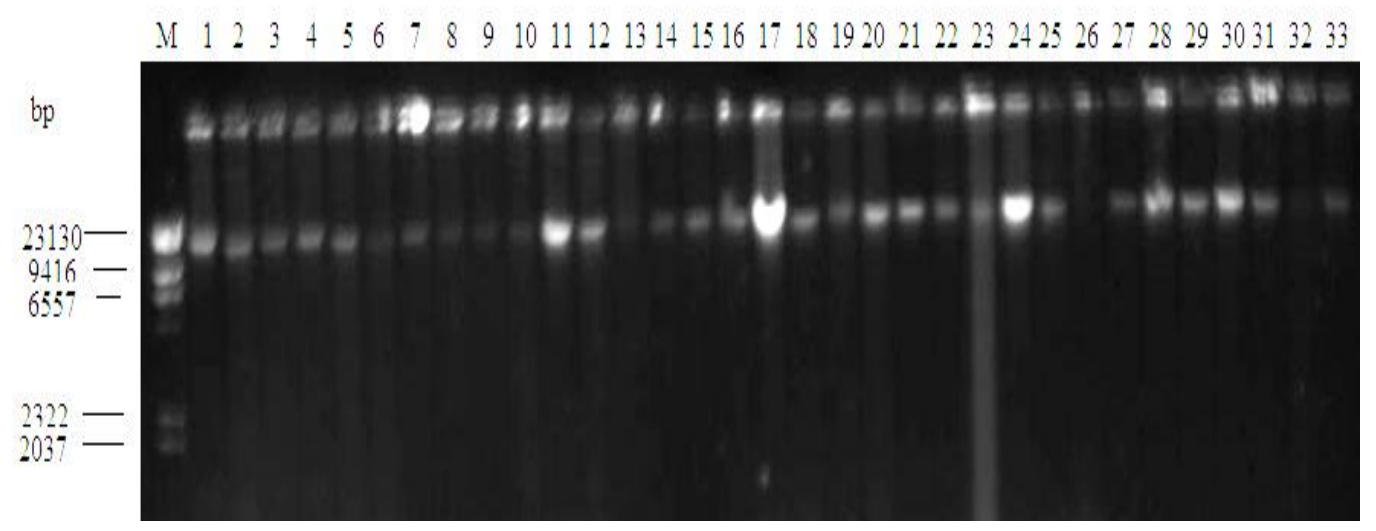

Fig. 4: plasmid profile of $E$. coli isolates obtained from well water during raining season analysed by $0.8 \%$ agarose gel electrophoresis after staining with ethidium bromide and the DNA bands were visualised by UV-transilluminator.

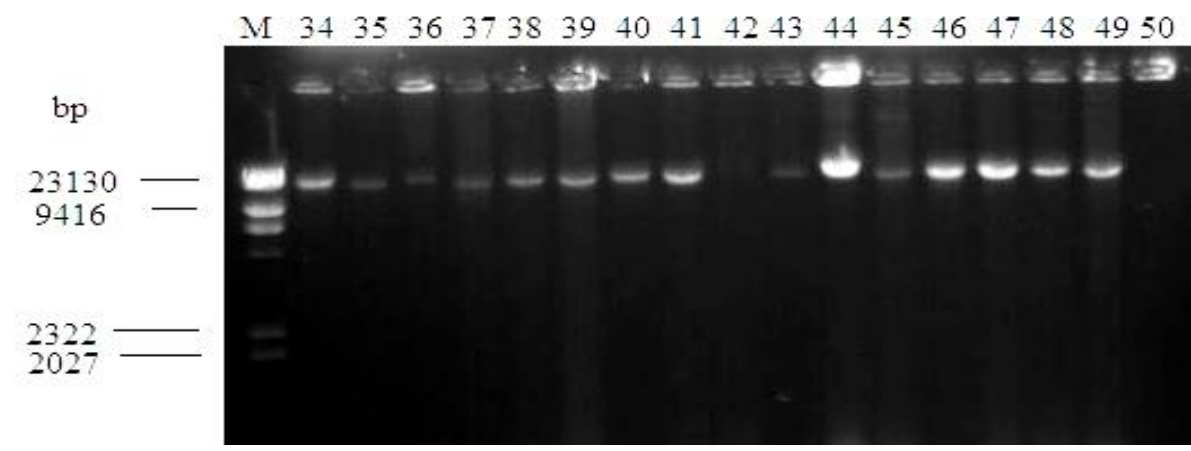

Fig. 5: plasmid profile of $E$. coli isolates obtained from well water during dry season analysed by $0.8 \%$ agarose gel electrophoresis after staining with ethidium bromide and the DNA bands were visualised by UVtransilluminator. 


\section{DISCUSSION}

The fact, that water is essential to all known forms of life cannot be over emphasized. The provision of clean drinking water and discharge of adequately treated wastewater is a fundamental requirement for human life [19]. man need water for industrial development, Irrigation to grow food, wash everyday item, sanitations needs, water makes up about $90 \%$ of cytoplasm, water is used as hydration to sustain health among others. However, inadequate safe drinking water, lack of proper sewage disposal system and drainage system and inadequate general environmental sanitation measures had resulted into a number of water diseases that claims millions of lives every year in developing countries [20]. Major factors affecting the microbial quality of surface water and underground waters are sewage disposal treatment surface runoff water, seepage from nearby sewage or septic tank [21]. Most wells are often highly contaminated were there are high concentration of physical and chemical parameter above the acceptable standard [22].

The results of this research revealed the E. coli count, the plasmid profile and the antibiotic sensitivity pattern of the $E$. coli isolates of the well water samples in Akure metropolis. This is to ascertain whether or not the well water is microbiologically safe for human consumption and other domestic use. According to the result obtained in this study it was revealed that of the four hundred samples well water sourced during the dry season, (76) well water sample representing $19 \%$ of the 400 sample sourced contain E. coli while 108 representing $27 \% 400$ well water sample collected during the raining season contain $E$. coli. this corroborated the findings of [23] who reported $28.72 \%$ of E.coli occurrence in rain water in Ondo state. An indication that seasonal variation greatly has effect on the microbiological quality of the well water. The presence of this organism in the well water studied has an implication for public health. Species of this organism have been associated with human intestinal diseases [24]. However, this result is contrary or against WHO recommendation of zero $E$ coli in $100 \mathrm{ml}$ water sample [25].

Highest recovery of $E$. coli from Isolo metropolis during the raining season is an indication that the water has been subjected to faecal contamination which may occur as a result of poor sanitation, closeness of the well to a pit latrine, poor sewage disposal systems, surface runoff and seepage from contaminated ground water and waste water [26]. [27,28,29,30]stated that water sources such as well and river serve as natural habitat for pathogenic $E$. coli strains that possess virulence factors that could cause gastrointestinal diseases. The virulence strains of $E$. coli are categorically divided into enterotoxigenic E. coli (ETEC), enteropathogenic E. coli (EPEC), enteroaggretative E. coli (EAEC), enterohaemorrhagic E. coli (EHEC) and necrotoxigenic E. coli (NTEC) [31]. The antibiotic sensitivity patterns of the $E$. coli isolates obtained in this research reveals that larger percentage of the $E$. coli was resistant to one or more of the antimicrobial agent tested. [32] reported more than 50\% isolates of vibro species to showed resistance against five commonly used antibiotics : ampicillin, ceftadizime, erythromycin, chloramphenicol, cefuroxime. The findings in the present study reveal high percentage of $E$. coli isolates being resistant to Amoxacillin (AM), Sulphamethoxazole (SXT), and Chloranphenicol (CH). [33] reported multiple resistance to antibiotic by strains of E.coli. [34] reported E.coli isolates to be resistant to antibiotic such as Amoxacillin (AM), Sulphamethoxazole (SXT) and chloramphenicol. The fact that some of these $E$. coli isolates show high level of resistance to some of the antimicrobial agents used is an indication that theses antibiotics have been abused or often used for the treatment of bacterial infection hence, the possibility of building resistance against the antimicrobial agent. [35] reported multi resistant pattern of the E.coli isolates of urinary tract infection.

The results from this research revealed that of all the E. coli isolates, isolates from well water obtained from Isolo revealed the highest level of resistance to one or more antimicrobial agent. This may also be attributed to the transfer of resistance gene (plasmid) from one organism to another since plasmids are easily acquired by organisms. The high microbial load of the well water in this metropolis may be a significant factor in transferring resistance gene from one organism to another. Resistance pattern may demonstrate multiple resistances to many antimicrobial agents and could have therapeutic consequences. The detection of many $E$. coli isolates resistant patterns was not unexpected. Resistance to antimicrobial agents is most common in areas with high usage of antibiotics such as hospitals [36]. The observed rare bacterial resistance to Trivid, Aumentin and pefloxacin has been attributed to the restricted use of the drug. [37]. The low toxicity of some of the antibiotics use in this research has resulted in the overuse in the medical community, hence the observed increased resistance. Plasmid profile analysis of 50 E.coli isolates by agarose gel electrophoresis showed a total of 48 different plasmid bands occuring in various combinations. [38] found 25 different plasmid bands in $63 E$. coli isolates. The distribution of different plasmids among these isolates appeared to have been at random. The plasmid profiles were compared with reference DNA molecular weight marker (Hind III digest of Lambda DNA). After electrophoresis, the band size was estimated by careful eyes estimation. There was little interrelationship between the plasmid profile pattern 


\section{CONCLUSION}

The microbiological analysis of the well water sample used in this research did not meet the recommended limits and could pose a serious health risk to consumers if used. This emphasizes the urgent need of Government intervention in the provision of safe water supply and provision of proper sanitation facilities for people living in Akure metropolis.

\section{REFERENCES}

[1] Wilkes G, Edge T, Gannon V, Jokinen C, Lyautey E, Medeiros D, Neumann N, Ruecker N, Topp E, Lapen DR (2009) Seasonal relationships among indicator bacteria, pathogenic bacteria, Cryptosporidium oocysts, Giardia cysts, and hydrological indices for surface waters within an agricultural landscape. Water Res 43:2209-2223

[2] Onyenekenwa, C. E (2011). Effects of Water and Sanitation Crisis on Infants and Under-five Children in Africa. Journal of Environmental Science and Technology 4(2):103-111

[3] Venter SN (2001) Microbial water quality in the 21st century. SA Water Bull 27:16-17

[4] Nevondo TS, Cloete TE (1999) Bacterial and chemical qualities of water supply in Dertig Village Settement. Water SA 25:215220

[5] Lehloesa LJ, Muyima NYO (2000) Evaluation of impact of household treatment procedures on the quality of groundwater supplies in the rural community of the Victoria District, Eastern Cape. Water SA 26:285-290

[6] Kroening SE (1999) Faecal Coliform and Escherichia coli Bacteria in the St. Croix National Scenic Riverway, Summer. WaterResources Investigations Report, 00-4214 U.S. Geological Survey, $p$ 1-8

[7] Ram S, Vajpayee P, Shanker R (2008a) Contamination of potable water distribution system by multi-antimicrobial resistant enterohaemorrhagic Escherichia coli. Environ Health Perspective 116:448-452

[8] Obi CL, Potgieter N, Bessong PO, Matsaung G (2002) Assessment of the microbial quality of river water sources in rural communities in South Africa. Water SA 28:287-292

[9] Ram S, Vajpayee P, Tripathi U, Singh RL, Seth PK, Shanker R (2008b) Determination of antimicrobial resistance and virulence gene signatures in surface water isolates of Escherichia coli. J Appl Microbiol 105:1899-1908

[10] White DG, Hudson C, Maurer JJ, Ayers S, Zhao S, Lee MD, Bolton L, Foley T, Sherwood J (2000) Characterization of chloramphenicol and florfenicol resistance in Escherichia coli associated with bovine diarrhoea. J Clin Microbiol 38:4593-4598 WHO(2004) World Health Organization. Guideline for water quality. $3^{\text {rd }}$ edition, volume 1 Geneva.

[12] Driscoll,F.(1986). Groundwater and Wells. St. Paul: Johnson Filtration Systems. ISBN 978-0-9616456-0-1.
[13] Committee on Environmental Health; Committee on Infectious Diseases (2009). "Drinking water from private wells and risks to children". Pediatrics 123 (6): 1599-1605.

[14] Eckburg PB, Bik EM, Bernstein CN, Purdom E, Dethlefsen L et al (2005). "Diversity of the human intestinal microbial flora". Science 308 (5728):1635-1638. doi:10.1126/science.1110591. PMC 1395357.PMID 15831718.

[15] Edward, P.R. and Ewing, W.H. (1972). Identification of Enterobacteriaceae, 3rd ed. International Student Publication, Burgess, pp 26-28.

[16] Forbes, B.A., Sahm, D.F. and Weissfeld, A.S. (1998). Diagnostic microbiology, Vol 10. Mosby, St. Louis, Pp 384-388.

[17] Leclerc H. Messel DAA, Edberg SC, Struijk CB (2001) Advance in bacteriology of the coliform group: their sustainability as markers of microbial water safety. Ann Rev Microbiol 55:201-234.

[18] National Committee for Clinical Laboratory Standards (NCCLS). (2000). Performance standards for antimicrobial disk susceptibility tests. NCCLS document M2-A7. National Committee for Clinical Laboratory Standards, Wayne.

[19] Akpor, O.B and Muchie, M. 2011. Challenges in Meeting the MDGs: The Nigerian Drinking Water Supply and Distribution Sector. Journal of Environmental Science and Technology, 4: 480-489.

[20] Zamxaka, M., Pironcheva, G. and Muyima, N.Y.O. (2004). Microbiological and physico-chemical assessment of the quality of domestic water sources in selected rural communities of the Eastern Cape Province, South Africa. Water SA 30:333-340.

[21] Fatoki, O.S., Muyima, N.Y.O. and Lujiza, N. (2001). Situation analysis of water quality in the Umtata River catchment. Water SA. 27:467-473.

[22] Tamer M. Alslaibi, Yunes K. Mogheir and Samir Afifi, 2011. Assessment of Groundwater Quality Due to Municipal Solid Waste Landfills Leachate. Journal of Environmental Science and Technology, 4: 419-436.

[23] Akharaiyi , F.C. Adebolu , T.T. Akponmendaye, D.E. and Omoya , F.O. 2007. Antibiotics Assay Pattern of Escherichia coli Isolates from Rainwater in Ondo State, Nigeria. International Journal of Biological Chemistry, 1: 179-183.

[24] National Research Council: Drinking Water and Health Disinfectants and Disinfectant By-Products. National Academy of Sciences, Volume 7, National Academy Press, 1987.

[25] WHO(2004) World Health Organization. Guideline for water quality. $3^{\text {rd }}$ edition, volume 1 Geneva.

[26] National Research Council: Drinking Water and Health Disinfectants and Disinfectant By-Products. National Academy of Sciences, Volume 7, National Academy Press, 1987.

[27] Kuhnert, P. Boerlin, P. Frey, J. (2000) Target genes of virulence assessment of Escherichia coli isolates from water, food and the environment. Fed Europ Microbiol Soc Rev 24:107-117

[28] Muller, E.E, Ehlers, M.M, Grabow,W.O.K(2001) The occurrence of E. Coli O157:H7 in South African water sources intended for direct and indirect human consumption. Water Res 35:3085-3088

[29] Obi, C.L, Green E, Bessong P.O, de Villiers B, Hoosen, A.A, Igumbor, E.O, Potgieter N (2004a) Gene encoding virulence markers among Escherichia coli isolates from diarrhoeic stool samples and river sources in rural Venda communities of South Africa. Water SA 30:37-41

[30] Ahmed W, Tucker J, Bettelheim K.A, Neller R, Katouli M (2007) Detection of virulence genes in Escherichia coli of an existing metabolic fingerprint database to predict the sources of pathogenic E. coli in surface waters. Water Res 41:3785-3791

[31] Huang D.B, Mohanty A, DuPont H.L, Okhuysen P.C, Chiang T (2006). A review of an emerging enteric pathogen: enteroaggregative Escherichia coli. J Med Microbiol 55:1303-1311

[32] Sharma, A. Bora, C.R. Chaurasia, R.K. and Vandana Sahu, 2009. Antibiotic Susceptibility and Genetic Analysis of Vibrio Species Isolated from Reverine Environment. Current Research in Bacteriology, 2: 36-49.

[33] Ramesh, S. Manivasagan, P. Ashokkumar, S. Rajaram, G. and Mayavu, P. 2010. Plasmid Profiling and Multiple Antibiotic Resistance of Heterotrophic Bacteria Isolated from Muthupettai Mangrove Environment, Southeast Coast of India. Current Research in Bacteriology, 3: 227-237. 
[34] Manikandan, S. Ganesapandian, S. Manoj Singh and Kumaraguru, A.K. 2011. Emerging of Multidrug Resistance Human Pathogens from Urinary Tract Infections. Current Research in Bacteriology, 4: 9-15.

[35] Sevanan Murugan, Pongiya Uma Devi and Peedikayil Neetu John, 2011. Antimicrobial Susceptibility Pattern of Biofilm Producing Escherichia coli of Urinary Tract Infections. Current Research in Bacteriology, 4: 73-80.

[36] Sternbuerg, S. (1999). Antimicrobial resistance in bacteria in pets and horses. Acta. Vet. Scand. Suppl. 92: 37-50.

[37] Goni-Urriza M, Capdepuy M, Arpin C, Raymond N, Caumette P, Quentin C (2000) Impact of an urban effluent on antibiotic resistance of riverine Enterobacteriaceae and Aeromonas spp. Appl Environ Microbiol 66:125-132

[38] Faruque, S.M., Haider, K., Rahman, M.M., Alim, A.R.M.A., Baqui, A.H., Abmady, Q.S., Hussain K.M.B., and Albert, M.J. (1992). Evaluation of a DNA probe to identify entero- aggregative E.coli from children diarrhea in Bangladesh. J. Diarrheal Dis. Res., $10: 314$ 